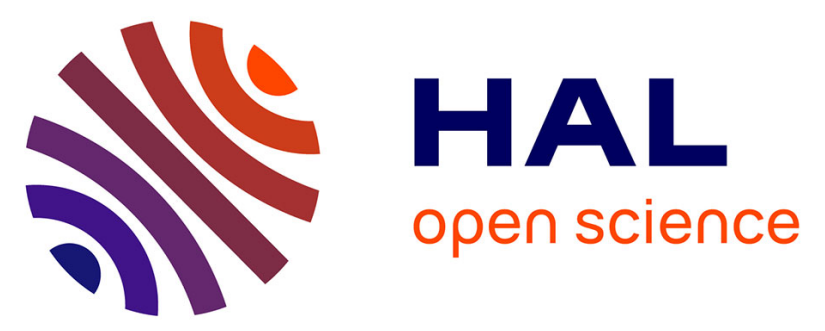

\title{
Effect of the nutritional status of Creole goats on the density-dependent prolificacy of Haemonchus contortus
}

Steve Cériac, Priscilla Durbant, Xavier Godard, Claude Barbier, Dalila

Feuillet, Yoann Félicité, Harry Archimède, Jean-Christophe Bambou

\section{- To cite this version:}

Steve Cériac, Priscilla Durbant, Xavier Godard, Claude Barbier, Dalila Feuillet, et al.. Effect of the nutritional status of Creole goats on the density-dependent prolificacy of Haemonchus contortus. Veterinary Parasitology, 2019, 276, pp.108973. 10.1016/j.vetpar.2019.108973 . hal-02952936

\section{HAL Id: hal-02952936 \\ https: / hal.inrae.fr/hal-02952936}

Submitted on 29 Sep 2020

HAL is a multi-disciplinary open access archive for the deposit and dissemination of scientific research documents, whether they are published or not. The documents may come from teaching and research institutions in France or abroad, or from public or private research centers.
L'archive ouverte pluridisciplinaire HAL, est destinée au dépôt et à la diffusion de documents scientifiques de niveau recherche, publiés ou non, émanant des établissements d'enseignement et de recherche français ou étrangers, des laboratoires publics ou privés. 


\title{
Effect of the nutritional status of Creole goats on the density-dependent prolificacy of Haemonchus contortus
}

\author{
Steve Cériac ${ }^{\mathrm{a}}$, Priscilla Durbant ${ }^{\mathrm{a}}$, Xavier Godard ${ }^{\mathrm{b}}$, Claude Barbier ${ }^{\mathrm{b}}$, Dalila Feuillet ${ }^{\mathrm{a}}$, \\ Yoann Félicité ${ }^{\text {, Harry Archimède }}{ }^{\mathrm{a}}$, Jean-Christophe Bambou ${ }^{\mathrm{a}, *}$ \\ ${ }^{a}$ URZ, Unité de Recherches Zootechniques INRA, 97170, Petit-Bourg (Guadeloupe), France \\ ${ }^{\mathrm{b}}$ PTEA, Plateforme Tropicale d'Expérimentation sur l'Animal INRA, 97170, Petit-Bourg (Guadeloupe), France
}

\section{A R T I C L E I N F O}

\section{Keywords:}

Haemonchus contortus

Goat kids

Nutrition

Prolificacy

Density-dependent

\begin{abstract}
A B S T R A C T
The objective of this study was to measure the effect of the nutritional status of Creole goat kids on the host responses and the nematode population established after an experimental H. contortus infection. Fifty six kids were fed with 4 diets corresponding to 2 nutritional statuses: the low nutritional status (HAY, hay ad libitum and HB, Hay ad libitum + banana) and the high nutritional status (HS, hay ad libitum + soya meal and HSB, hay ad libitum + banana + soya meal). For each diet, 8 kids were experimentally infected with 10,000 H. contortus infective larvae (L3) and 6 kids were kept as non-infected controls. From the day of infection until 6 weeks postinfection, samples were collected to measure individual intake, total tract digestibility, parasitological and hematological parameters. The dry matter intake (DMI), the average daily gain (ADG), the crude protein (CP) and the digestible CP intake were higher in goats fed the HS and HSB diets, but no statistically significant interaction between the nutritional status and the infection was observed. The packed cell volume (PCV), the red blood cell counts (RBC) and the mean corpuscular volume (MCV) were higher with the HS and the HSB diets. In kids with the high nutritional status the nematode burden and pathophysiological impact of the infection were significantly lower but not the FEC. In conclusion, this reduced establishment rate was associated with an increased production of eggs by the female parasites and suggested a phenomenon of density-dependent prolificacy of $\mathrm{H}$. contortus probably inherent to the fitness of the parasite population.
\end{abstract}

\section{Introduction}

For a long time, the main strategy against gastrointestinal parasitism was the eradication of gastrointestinal nematodes (GIN) by the use of chemical molecules (i.e. anthelmintics). Although the development of resistance against these molecules was observed since the beginning, this strategy was not questioned until the emergence of resistance against almost all the available molecules (Jackson and Coop, 2000; Papadopoulos, 2008; Ploeger and Everts, 2018). Moreover, the negative impact of these drugs on soil biodiversity coupled with concerns over the presence of residues in animal products led some states in the world to advocate a significant reduction of the use of chemical molecules in animal production (Adler et al., 2016; Beynon et al., 2015; Horvat et al., 2012). Consequently, alternative control strategies have to be developed complementary to a parsimonious use of classical practices for the control of GIN infections which remain of major concern in small ruminant husbandry.

Research efforts have focused on three main aspects: i) the reduction of the risk of contact between ruminants and GIN mainly by grazing management strategies; ii) the improvement of host resistance by genetic selection, the use of effective vaccine and nutritional strategies and iii) the improvement of the efficacy of anthelmintics by the reduction of their use with targeted drenching and the use of neutraceutical plant resources (Alonso-Díaz et al., 2008; van Wyk and Bath, 2002). The control of GIN infections should be included in a global scheme of parasitism management aimed at avoiding rampant parasitism which is out of control and decreasing the risk of parasite populations developing increased anthelmintic resistance and virulence.

GIN infections are often assimilated to a nutritional disease because of the major negative impacts on diet intake, total tract digestibility and the reorientation of nutrient use for the maintenance of tissue homeostasis (Hoste et al., 2016). Consequently, the nutritional strategy, which is generally over-nutrition with concentrate feeds, aims to provide nutrients that enable the animal to compensate for losses caused by the GIN. It has been shown that protein supplementation reduced faecal egg counts and anorexia and offset the increase in protein turnover

\footnotetext{
* Corresponding author.

E-mail address: jean-christophe.bambou@inra.fr (J.-C. Bambou).
} 
induced by Haemonchus contortus, a highly pathogenic blood feeder GIN (Abbott et al., 1986,1988; Shaw et al., 1995; Strain and Stear, 2001). Indeed, the positive impacts of energy and protein on resistance and resilience of sheep and goats to GIN infections have been recently shown in a meta-analysis (Cei et al., 2018). Moreover, the metabolic cost of GIN infections have been estimated in lambs (Mendez-Ortiz et al., 2019). However, most available data come from sheep, underscoring the need for more experiments in goats.

Recently, it has been shown in Creole goat kids that protein overnutrition increased resilience but not resistance to an experimental $\mathrm{H}$. contortus infection by reducing anemia through an increased hematological regeneration capacity of the bone marrow (Ceriac et al., 2017). However, in this study the effect of the nutritional status on the GIN populations was measured only through the FEC and the impact of the experimental $\mathrm{H}$. contortus infection on intake and digestibility was not performed. Here, we monitored individually all the animal responses to measure finely the impact of nutritional status on the host-parasite interactions.

\section{Materials and methods}

\subsection{Animals, diets and experimental design}

The experiment was carried out in the experimental animal facilities of the French National Agronomic Research Institute (INRA, certificate number A-971-18-02) in Guadeloupe (French West Indies, latitude $16.16 \mathrm{~N}$, longitude $61.30 \mathrm{~W}$ ). In accordance with the current law on animal experimentation and ethics, this experiment was approved by the French Ministry of Agriculture after evaluation by the Animal Care and Use Committee of French West Indies and Guyana (authorization number: HC-69-2014-1). The experiment lasted 4 months. All the kids were raised on pasture and naturally infected by GIN before the experiment. The kids were drenched with levamisole (Polystrongle ${ }^{\circledR}$, Merial, Lyon, France, $7,5 \mathrm{mg} / \mathrm{kg} \mathrm{LW}$ ), ivermectin (Oramec ${ }^{\circledR}$, Merial, Lyon, France, $0,2 \mathrm{mg} / \mathrm{kg} \mathrm{LW}$ ) and praziquantel (Cestocur ${ }^{\circledR}$, Bayer Santé, Puteaux Fance, $375 \mathrm{mg} / \mathrm{kg} \mathrm{LW}$ ) before being placed indoors in individual pens for the experiment. Thereafter, the kids had a 7-week adaptation period to the individual pens and the diets. Two faecal egg counts performed during this period confirmed the parasite-free status of the kids. Four diets were evaluated ( $n=14$ kids/diet): 1 ) Hay ad libitum (HAY); 2) Hay ad libitum + $1250 \mathrm{~g}$ slices green banana (HB); 3) Hay ad libitum $+250 \mathrm{~g}$ of soybean meal (HS); 4) Hay ad libitum $+250 \mathrm{~g}$ of soybean meal $+1250 \mathrm{~g}$ slices green banana (HSB). The chemical composition of the ingredients of the diets is presented in Table 1 . Thereafter, 32 kids ( $n=8$ per group) were experimentally infected (I) with a single oral dose of $10,000 \mathrm{H}$. contortus stage 3 larvae (L3) and 24 kids remain non-infected (NI). The H. contortus L3 were obtained by coproculture of faeces provided by donor kids (Bambou et al., 2008). Briefly, 200-300 g of faeces were placed in a plastic container covered with absorbent paper and were kept moist at room temperature for 8 days.

Table 1

Chemical composition of Dichantium sp. Hay, soybean meal and green banana.

\begin{tabular}{llll}
\hline Feeds & & & \\
\hline Items & Hay & Soybean Meal & Banana \\
Dry matter, g/kg & 830.0 & 890.0 & 210.0 \\
Organic matter, g/kg DM & 912.1 & 914.9 & 944.1 \\
Crude Protein, g/kg DM & 91.5 & 565.7 & 55.5 \\
Neutral Detergent Fiber, g/kg DM & 707.5 & 602.0 & 170.6 \\
Acid Detergent Fiber, g/kg DM & 566.0 & 84.4 & 127.0 \\
Acid Detergent Lignin, g/kg DM & 64.4 & 10.3 & 29.1
\end{tabular}

\subsection{Animal samples, diet samples and measurements}

The kids were weighed at the beginning of the experiment and every week until the end. Average Daily Gain was estimated by regression of live weight over time. The dry matter (DM) intake was measured and the apparent total-tract digestibility of the organic matter and crude proteins (OM, CP) were calculated. The quantities of feed offered and refused were weighed daily to measure individual intake. The feces were collected during 5 consecutive days during 9 periods (pre- and post-infection) over the entire duration of the experiment with bags glued at the back of the animals. Representative samples of the forage offered and refused and feces were taken daily, dried at $60^{\circ} \mathrm{C}$ for 3 days in a ventilated oven to determine the DM content and to determine the chemical composition.

After experimental infection, blood samples of each kid were collected once a week by jugular venipuncture using disposable syringes and 20-Ga needles. A 2.5-mL blood sample was collected in commercial anticoagulant tubes (ethylenediamine tetraacetic acid K3, EDTA tubes; Becton Dickinson, Plymouth, UK). Blood samples were analyzed by an automaton (Melet Schloesing, MS9-5s, Osny, FRANCE), to measure Pack Cell Volume (PCV), red blood cells count (RBC), blood platelets and mean corpuscular volume of the RBC (MCV). The number of blood eosinophils was counted with a Malassez cell counter (Dawkins et al., 1989)

Blood samples collected in plastic tubes (Becton Dickinson, New Jersey, USA) were centrifuged for $5 \mathrm{~min}$. at $5000 \mathrm{rpm}$ at $4{ }^{\circ} \mathrm{C}$, and serum was then frozen at $-20 \circ \mathrm{C}$ until analysis. Serum pepsinogen levels were determined using a micro method for routine determination (Dorny and Vercruysse, 1998). The serum pepsinogen level, measured weekly, is used as an indicator of the mucosal damage caused by $\mathrm{H}$. contortus infection. Each sample was measured in triplicate for each time point. A coefficient of variation of $\leq 15 \%$ was considered acceptable.

Faecal egg counts (FEC, eggs/g feces), were measured with a modified McMaster method for rapid determination (Bambou et al., 2008). After the experimental infection, approximately a $10 \mathrm{~g}$ faecal sample was collected weekly on each kid directly from the rectum. The feces were kept in plastic tubes to avoid contamination and immediately transported to the laboratory in refrigerated vials. The faeces were collected twice a day in collection bags that had been fitted to each animal and weighed. The total faecal eggs excreted per day (TFEC) was calculated as follow: TFEC $=$ FEC (eggs per gram of faeces) $\times$ weight of total faeces excreted per animal per day $(\mathrm{g})$. The adult female H. contortus prolificacy (i.e. mean number of eggs produced per female adult nematode per day) was calculated as follow: Prolificacy = TFEC/ number of adult female $\mathrm{H}$. contortus. To measure the worm burden, the contents of the abomasum of infected animals were collected individually after slaughtering at 6 weeks post-infection. The parasites were collected, counted and sorted (Bambou et al., 2013).

\subsection{Chemical analysis}

Dried diet and feces samples were milled through a 1-mm screen (Reich hammer mill, Haan, Germany) prior to analysis. Organic matter (OM) and $\mathrm{N}$ analyses were performed according to AOAC (1990, Methods 923.3 and 992.15 , respectively) by ashing at $550{ }^{\circ} \mathrm{C}$ for $6 \mathrm{~h}$ for $\mathrm{OM}$ and by the Dumas method for N. Nitrogen analyses of fresh urine samples were performed according to the same method as for the diets. Crude protein $(\mathrm{CP})$ was calculated as $\mathrm{N} \times 6.25$. Cell wall components (neutral detergent fibre (NDF), acid detergent fibre (ADF) and acid detergent lignin (ADL) in diet and feces were determined using a sequential procedure (AOAC, 2006, Methods 200.04 and 973.18, respectively for NDF and ADF and ADL).

\subsection{Statistical analysis}

Data were analyzed by a linear mixed model using the PROC MIXED 
of SAS (Version 9, SAS Inst., Inc., Cary, NC, 1999). FEC and eosinophilia variables were logarithm transformed (ln (FEC +15$)$, ln (Blood eosinophils +1 ) respectively) and the other hematological data were square-root transformed, to normalize residual variances. The model included fixed effects of the diet (D), the infection status (I), the weeks post-infection ( $\mathrm{T}$ ) and the interaction between $\mathrm{D}$ and I as defined below:

$y_{i j k l m}=\mu+D_{i}+I j+T_{k}+\left(D_{i} \times I j\right)_{i j}+\varepsilon_{i j k}$

where $y$ is the observed values; $\mu$ the overall mean; $D_{i}$ the fixed effect of the ith dietary condition ( $i=1$ to 4$), \mathrm{Ij}$ the fixed effect of the $\mathrm{j}^{\text {th }}$ infection status (infected vs non-infected), $T_{k}$ the fixed effect of the $k^{\text {th }}$ week post infection ( $\mathrm{k}=0$ to 6$)$ and $(\mathrm{D} \times \mathrm{I})^{\mathrm{ij}}$ the interaction of the diet and infection status. These same analyses were carried out for all the variables and the fixed effects were taken into account when significant $(\mathrm{P}<0.05)$

\section{Results}

\subsection{Intake, digestion and performance}

The DM, OM and digestible OM (DOM) intakes post-infection were significantly higher in HSB and HS than HAY and HB diets $(\mathrm{P}<0.05$, Table 2). No significant effect of the infection and no interaction with the diets or the weeks post-infection were observed $(\mathrm{P}>0.05)$. The $\mathrm{CP}$ and digestible $\mathrm{CP}$ intakes increased significantly in accordance with the hierarchy HB, HAY, HSB and HS diets $(P<0.0001)$. Significant interactions between the diets and the week post-infection were observed for the CP and DCP intakes and CP digestibility (Table 2, Fig.1A and B). No significant effect of infection and no interaction of the infection and the diet or the weeks post-infection were observed $(P>0.05)$. There was a significant effect of the diet on the ADG $(P<0.0001$, Fig. 4). The highest ADG were observed with HS and HSB and the lowest were observed with HAY and HB $(P<0.0001$, Table 2). No significant effect of the infection was observed on the ADG whatever the diet.

\subsection{Parasitological and parameters}

The FEC remained at zero until 2 weeks post-infection (w.p.i.) then increased significantly whatever the diet from 3 until 6 w.p.i. (Fig. 2).
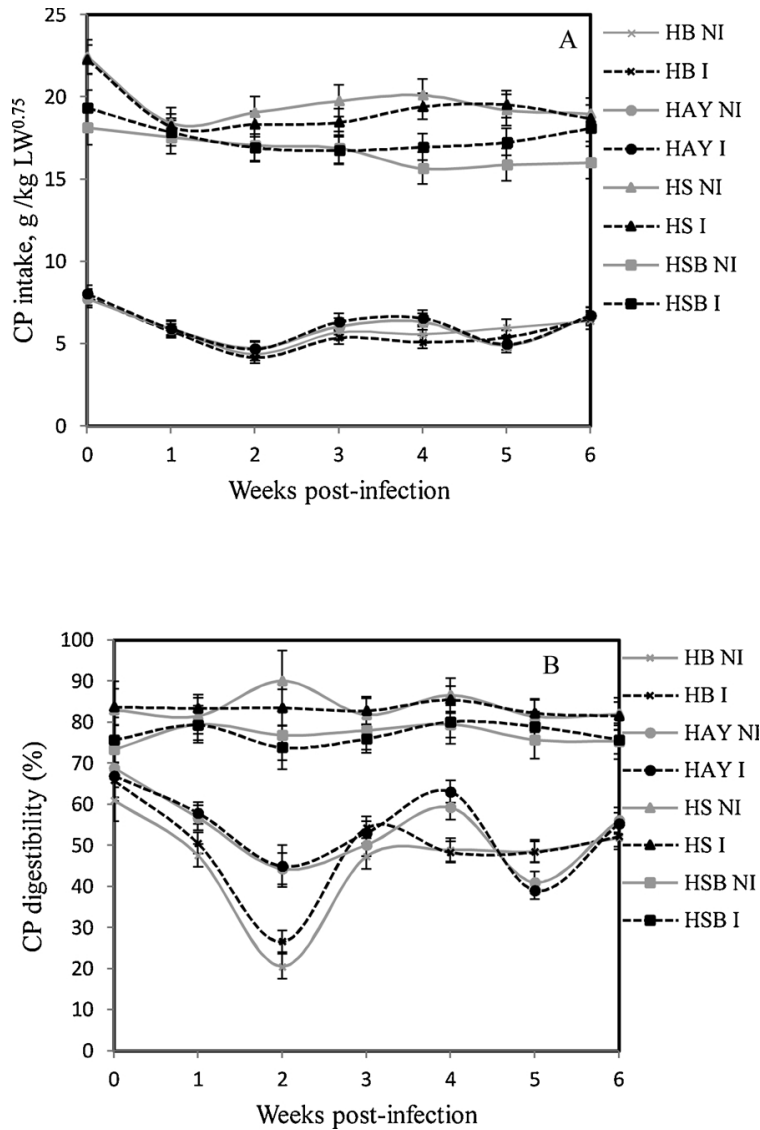

Fig. 1. Least square means of crude protein (CP) intake (A) and digestibility (B) of Creole goat kids infected (I) experimentally with $\mathrm{H}$. contortus and non-infected (NI) according to the diets: hay (HAY), hay and banana (HB), hay and soya meal (HS), hay with banana and soya meal (HSB).

No interaction between the diet and the weeks post-infection was observed $(P>0.05)$. No significant effect of the diet was observed on the FEC and the nematode burden (Fig. 2 and Table 3). In contrast, a

Table 2

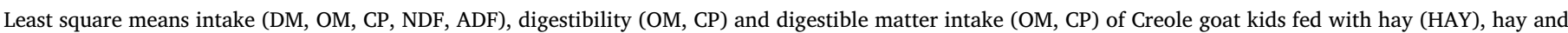
banana (HB), hay and soya meal (HS), hay with banana and soya meal (HSB) after experimental H. contortus infection.

\begin{tabular}{|c|c|c|c|c|c|c|c|c|c|c|c|}
\hline \multicolumn{6}{|l|}{ Diets } & \multicolumn{6}{|l|}{ P-value } \\
\hline Items & HAY & $\mathrm{HB}$ & HS & HSB & SEM $^{1}$ & $\mathrm{D}^{2}$ & $\mathrm{I}^{3}$ & $\mathrm{~T}^{4}$ & $\mathrm{D} \times \mathrm{I}$ & $\mathrm{T} \times \mathrm{D}$ & $\mathrm{T} \times \mathrm{I}$ \\
\hline $\mathrm{DM}^{5}$ intake, $\mathrm{g} / \mathrm{LW}^{0.75}$ & $56.29^{c}$ & $64.10^{\mathrm{b}}$ & $70.87^{\mathrm{a}}$ & $74.23^{\mathrm{a}}$ & 1.61 & 0.0001 & 0.359 & 0.0001 & 0.177 & 0.7057 & 0.876 \\
\hline $\mathrm{OM}^{6}$ intake, $\mathrm{g} / \mathrm{LW}^{0.75}$ & $50.78^{c}$ & $58.76^{\mathrm{b}}$ & $64.06^{\mathrm{a}}$ & $67.85^{\mathrm{a}}$ & 1.47 & 0.0001 & 0.28 & 0.0001 & 0.18 & 0.6232 & 0.8398 \\
\hline $\mathrm{CP}^{7}$ intake, $\mathrm{g} / \mathrm{LW}^{0.75}$ & $6.08^{\mathrm{c}}$ & $5.80^{\mathrm{c}}$ & $19.46^{\mathrm{a}}$ & $17.15^{\mathrm{b}}$ & 0.24 & 0.0001 & 0.755 & 0.0001 & 0.146 & 0.0009 & 0.904 \\
\hline OM Digestibility & $0.64^{\mathrm{c}}$ & $0.73^{\mathrm{a}}$ & $0.74^{\mathrm{ab}}$ & $0.78^{\mathrm{a}}$ & 0.01 & 0.0001 & 0.111 & 0.0001 & 0.704 & 0.53 & 0.7989 \\
\hline CP Digestibility & $0.53^{c}$ & $0.47^{\mathrm{d}}$ & $0.83^{\mathrm{a}}$ & $0.78^{b}$ & 0.01 & 0.0001 & 0.302 & 0.0001 & 0.66 & 0.0001 & 0.9603 \\
\hline Digestible $\mathrm{OM}$ intake, $\mathrm{g} / \mathrm{LW}^{0.75}$ & $32.47^{\mathrm{c}}$ & $43.24^{\mathrm{b}}$ & $47.89^{\mathrm{a}}$ & $51.99^{\mathrm{a}}$ & 1.4 & 0.0001 & 0.152 & 0.0001 & 0.413 & 0.5954 & 0.9232 \\
\hline DCP intake, $\mathrm{g} / \mathrm{LW}^{0.75}$ & $3.27^{\mathrm{c}}$ & $2.76^{\mathrm{d}}$ & $16.17^{\mathrm{a}}$ & $13.13^{\mathrm{b}}$ & 0.24 & 0.0001 & 0.31 & 0.0001 & 0.63 & 0.0001 & 0.985 \\
\hline $\mathrm{NDF}^{8}$ intake, $\mathrm{g} / \mathrm{LW}^{0.75}$ & $43.71^{\mathrm{b}}$ & $27.03^{c}$ & $51.37^{\mathrm{a}}$ & $39.08^{\mathrm{b}}$ & 1.77 & 0.0001 & 0.857 & 0.0001 & 0.407 & 0.433 & 0.9934 \\
\hline $\mathrm{ADF}^{9}$ intake, $\mathrm{g} / \mathrm{LW}^{0.75}$ & $21.07^{\mathrm{a}}$ & $12.94^{\mathrm{c}}$ & $19.31^{\mathrm{a}}$ & $15.67^{\mathrm{b}}$ & 0.92 & 0.0001 & 0.872 & 0.0001 & 0.225 & 0.025 & 0.9754 \\
\hline $\mathrm{ADG}^{10}, \mathrm{~g} / \mathrm{d}$ & $26.58^{\mathrm{b}}$ & $25.18^{\mathrm{b}}$ & $91.19^{\mathrm{a}}$ & $118.9^{\mathrm{a}}$ & 11.06 & 0.0001 & 0.2239 & - & 0.9824 & - & - \\
\hline
\end{tabular}

Means with different superscripts within each line differ significantly.

1 SEM: Standard Error of the Mean.

2 D: Diet.

${ }^{3}$ I: Infection status (infected vs non-infected).

4 T: Time (weeks post-infection).

5 DM: Dry Matter.

6 OM: Organic Matter.

7 CP: Crude Protein.

8 NDF: Neutral Detergent Fiber.

9 ADF: Acid Detergent Fiber.

10 ADG: Average Daily Gain. 


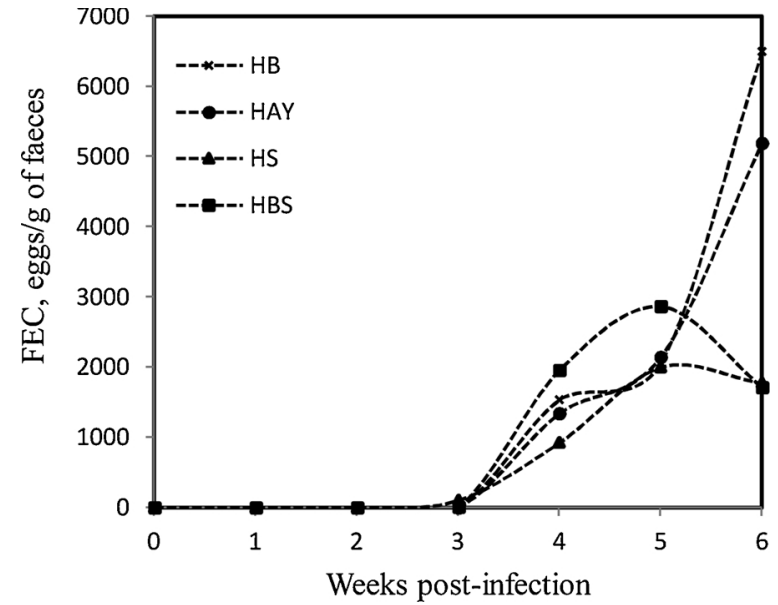

Fig. 2. Least square means of the faecal eggs count (FEC) of Creole goat kids infected experimentally with $\mathrm{H}$. contortus according to the diets: hay (HAY), hay and banana (HB), hay and soya meal (HS), hay with banana and soya meal (HSB).

Table 3

Abomasal worm counts of Creole goat kids fed with hay (HAY), hay and banana (HB), hay and soya meal (HS), hay with banana and soya meal (HSB) 6 weeks after experimental $\mathrm{H}$. contortus infection.

\begin{tabular}{|c|c|c|c|c|c|c|}
\hline & \multicolumn{4}{|l|}{ Diets } & \multirow[b]{2}{*}{ SEM $^{1}$} & \multirow[b]{2}{*}{ P-value } \\
\hline & HAY & $\mathrm{HB}$ & HS & HSB & & \\
\hline Male $^{2}$ & 348 & 651 & 210 & 246 & 127 & 0.07 \\
\hline Female $^{3}$ & $459^{\mathrm{a}}$ & $627^{\mathrm{a}}$ & $202^{\mathrm{b}}$ & $230^{\mathrm{b}}$ & 114 & 0.04 \\
\hline Nematode burden ${ }^{4}$ & 807 & 1278 & 414 & 478 & 239 & 0.06 \\
\hline Prolificacy ${ }^{5}$ & $6899^{\mathrm{a}, \mathrm{b}}$ & $4679^{a}$ & $14,192^{\mathrm{b}, \mathrm{c}}$ & $15,127^{\mathrm{c}}$ & 2835 & 0.04 \\
\hline
\end{tabular}

Means with different superscripts within each line differ significantly.

1 SEM: Standard Error of the Mean.

2 Male, total adult male nematodes.

3 Female, total adult female nematodes.

4 Nematode burden, total adult nematodes.

5 Prolificacy, mean number of eggs produced per female adult nematode per day.

significant effect of the diet was observed on the female nematode burden and their prolificacy (Table $3, \mathrm{P}<0.05$ ). The female nematode burden was significantly higher in the Hay and the HB diets compared with the HS and the HSB diets (459 and 627 vs 202 and 230 respectively, $\mathrm{P}=0.04$ ). In contrast, the prolificacy (eggs/day/female nematode) were lower in the Hay and the HB diets compared with the HS and the HSB diets (6899 and 4679 vs 14192 and 15127 respectively, $\mathrm{P}=0.04)$.

\subsection{Haematological parameters}

Before the experimental infection (Week 0 post-infection) the PCV and the RBC were significantly higher in the HSB and the HS diets compared with the HAY and the HB (Fig. $3 \mathrm{~A}$ and $\mathrm{B}, \mathrm{P}<0.05$ ). Thereafter, these two parameters decreased significantly from 2 until 4 w.p.i. in all the infected groups whatever the $\operatorname{diet}(\mathrm{P}<0.05)$. Between 5 and 6 w.p.i. a significant increase was observed in the infected groups $(\mathrm{P}<0.05)$. No significant variation was observed in the noninfected groups.

Significant effects of the infection status, the diet and the w.p.i. were observed on the MCV and the blood platelet concentration (Figs. 4 and $5, \mathrm{P}<0.002)$. The MCV increased significantly overtime in infected kids whatever the diet. Kids under the HS or the HSB diet had significantly higher MCV rate than kids fed with the HB diet or Hay $(\mathrm{P}<0.05)$. The MCV was not significantly different between the HAY
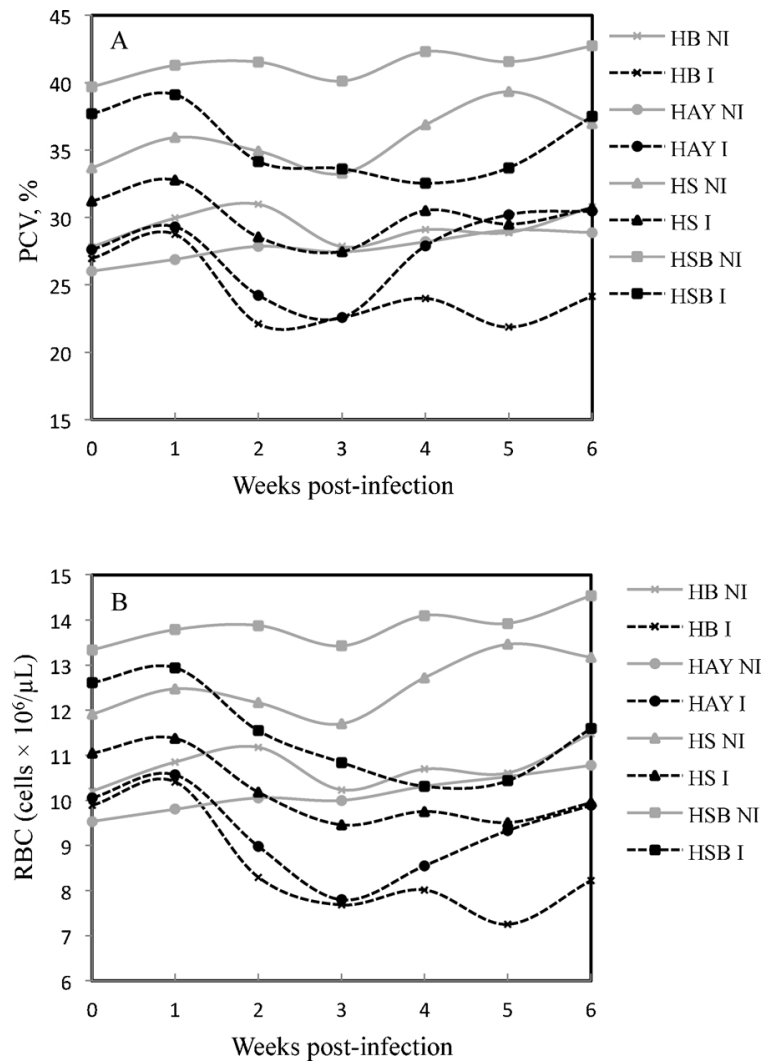

Fig. 3. Least square means of the packed cell volume (PCV, A) and red blood cell (RBC, B) of Creole goat kids infected (I) experimentally with $\mathrm{H}$. contortus and non-infected (NI) according to the diets: hay (HAY), hay and banana (HB), hay and soya meal (HS), hay with banana and soya meal (HSB).

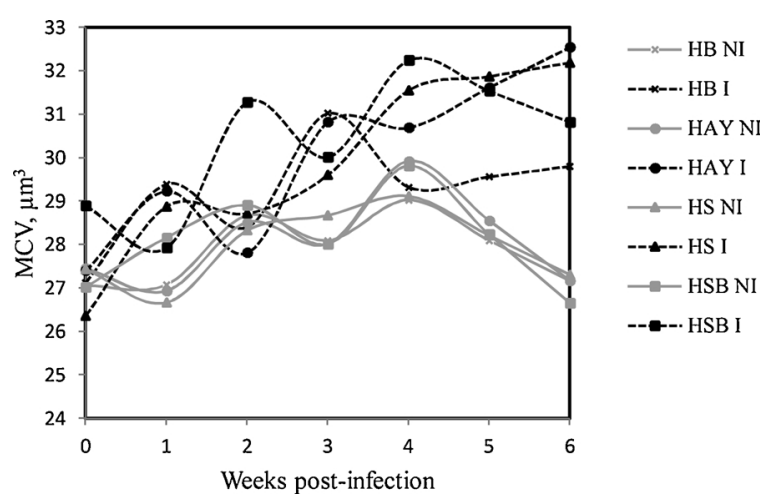

Fig. 4. Least square means of red blood cells mean corpuscular volume (MCV) of Creole goat kids infected (I) experimentally with $\mathrm{H}$. contortus and non-infected (NI) according to the diets: hay (HAY), hay and banana (HB), hay and soya meal (HS), hay with banana and soya meal (HSB).

and the HB diet and was significantly different between the HS diet and HSB diet $(P<0.05)$. Blood platelet concentration was lower in infected kids compared with the non-infected ones $(\mathrm{P}<0.0001)$. Kids fed with the HB diet had significant higher blood platelet than kids fed with HS diet or HSB diet. The blood platelet concentration of infected kids decreases significantly over time $(\mathrm{P}<0.0001)$.

Significant effects of the infection status, the diet and the w.p.i. were observed on serum pepsinogen concentration (Fig. $6, \mathrm{P}<0.0001$ ). The serum pepsinogen concentration of infected kids increased significantly over time and then decreased after 4 weeks post-infection $(\mathrm{P}<0.0001)$. From 1-5 weeks post-infection serum pepsinogen was higher in infected kids compared with the non-infected kids whatever 


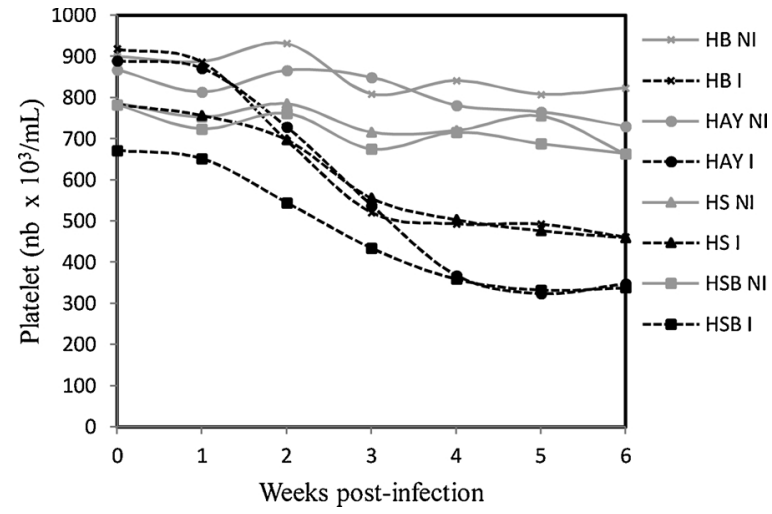

Fig. 5. Least square means of blood platelet concentration of Creole goat kids infected (I) experimentally with $\mathrm{H}$. contortus and non-infected (NI) according to the diets: hay (HAY), hay and banana (HB), hay and soya meal (HS), hay with banana and soya meal (HSB).

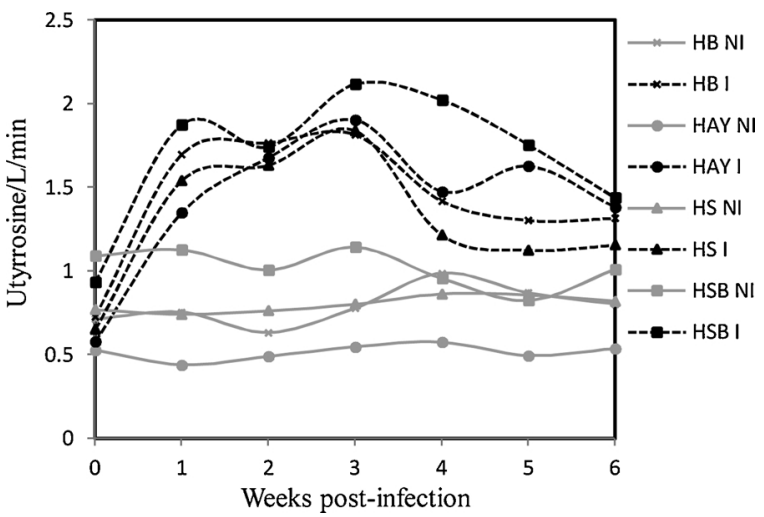

Fig. 6. Least square means of serum pepsinogen concentration of Creole goat kids infected (I) experimentally with $\mathrm{H}$. contortus and non-infected (NI) according to the diets: hay (HAY), hay and banana (HB), hay and soya meal (HS), hay with banana and soya meal (HSB). The pepsinogen concentrations were estimated with a direct method based on the hydrolysing effect of serum on buffered bovine albumin substrate which released tyrosine in the sample.

the diet $(\mathrm{P}<0.0001)$. At 4 weeks post-infection, kids fed with the HSB diet had the higher blood pepsinogen concentration.

\subsection{Blood eosinophil counts}

The blood eosinophils counts increased significantly in the infected kids to peak at 3 weeks post-infection (Fig. 7, P $<0.05$,). At 3 weeks post-infection the blood eosinophil counts were significantly higher in kids fed with the HS and the HAY diets than the HB diet $(\mathrm{P}>0.001)$. The lower increase was observed in kids fed with the HSB diet.

\section{Discussion}

The objective of this study was to measure the effect of the nutritional status of Creole goat kids on the host responses and the nematode population establishment after an experimental $\mathrm{H}$. contortus infection. In accordance with the nutritional requirements of goats estimated in a recent meta-analysis, we formulated four diets: two diets for the low nutritional status and two diets for the high nutritional status. The lowest ADG observed were for HAY and HB diets and the highest were for HS and HSB but no difference was observed between the diets of the similar nutritional status. No impact of the experimental infection on DMI was observed whatever the diet. Indeed, the significant decrease of DMI induced by $\mathrm{H}$. contortus infection would probably be dependent on the physiological stage (Cei et al., 2018; Coop and Kyriazakis, 2001).

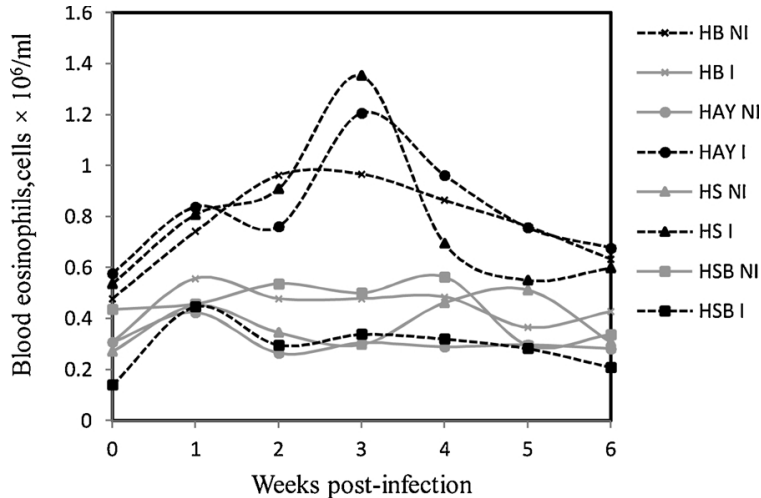

Fig. 7. Least square means of blood eosinophils concentration of Creole goat kids infected (I) experimentally with $\mathrm{H}$. contortus and non-infected (NI) according to the diets: hay (HAY), hay and banana (HB), hay and soya meal (HS), hay with banana and soya meal (HSB).

Anorexia would be more common with young animals when activating their immune system (Mendez-Ortiz et al., 2019). During this activating immune system period, DMI decreased from 20 to $50 \%$ against less than $5 \%$ in animals with a mature immune system (Bambou et al., 2009; Sykes, 2010). In keeping with our results, a decrease of the diet digestibility has also been reported, especially with GIN established in the abomasum (Cei et al., 2018). However this reduction has been associated with very high levels of infection and can be explained at least in part by a hypermotility of the gastro-intestinal tract, which accelerates the transit of digesta, decreases diet digestibility and increases protein losses (Bueno et al., 1982).

A significant effect of the diet was observed on the adult female nematode burden and the prolificacy but not on the FEC. Therefore, on the basis of the FEC and the serum pepsinogen, our results indicate that the high nutritional status did not allow the Creole kids to develop resistance against the $\mathrm{H}$. contortus infection. However, for the same FEC, the adult female nematode burden was lower and the prolificacy was higher with the HS and the HSB diets. The highest nutritional status would allow the control of the nematode establishment but not the prolificacy which would be probably modulated according to the worm burden. This density-dependent prolificacy of $\mathrm{H}$. contortus would be a mechanism of adaptation of the parasite which is probably more efficient for the selection of adaptive traits as shown for other GIN parasite (Churcher and Basanez, 2008; Michael and Bundy, 1989). These results are in contradiction both with the studies of Blackburn et al. (1991) and Bricarello et al. (2005), which reported that protein supplementation in sheep contributes to increase the host resistance (i.e. lower FEC and worm burden) or Wallace et al. (1996) showing that protein supplementation could improve the capacity to withstand the pathogenic effect of $\mathrm{H}$. contortus (i.e. host resilience). However, these studies were performed in sheep and the authors used trickle experimental infections whereas here we used a single infection. The dynamic of the parasite establishment would be different between these two experimental models.

The H. contortus infection disturbed the hematological parameters. The PCV as well as the RBC, were both significantly lower in infected kids compared with non-infected ones, confirming the anemia classically observed with $\mathrm{H}$. contortus infection. However, the anemia was significantly less pronounced in kids fed with the higher nutritional status, illustrating the potential to induce the expression of resilience. As recently shown, a higher MCV in infected kids suggested the induction of regenerative anemia to cope with the $\mathrm{H}$. contortus infection (Ceriac et al., 2019). However, the lowest adult female nematode burden observed in the highest nutritional status could also explain at least in part the lowest anemia. Similar results showing an increased MCV in goats supplemented with digestible crude protein during GIN 
infections had been described recently (Konwar et al., 2015). This could be explained in part by the fact that proteins are essential nutrients playing a central role in the activation of the immune system (Houdijk, 2012).

\section{Conclusion}

Resilience and resistance are two terms generally utilized to describe the response of small ruminants to GIN infection. The variables used for resilience are PCV (for $\mathrm{H}$. contortus infections), ADG for growing animals, milk and wool production; and for resistance the FEC and in some studies the parasite burden. Here we showed that when FEC is considered alone for the classification of the animal response as resilience could be misleading. Indeed, a significant effect of the nutritional status was observed for the nematode burden but not for FEC. The lower nematode burden was associated with a reduced pathophysiological impact of the infection. In conclusion, this reduced establishment rate associated with an increased production of eggs by the female parasites suggested a phenomenon of density-dependent prolificacy of $\mathrm{H}$. contortus probably implicated in the fitness of the parasite population.

\section{Declaration of Competing Interest}

The authors declare no competing interest in relation to this article.

\section{Acknowledgments}

The authors want to give thanks to the Duclos team for care and handling of the animals: P.-J. Dumoulin, F. Periacarpin and C. Deloumeaux. This study was funded by the Project Agroecodiv (La Région Guadeloupe and Fonds Européens FEDER) and the INRA métaprogramme GISA (Gestion Intégrée de la Santé Animale) Project Strep (drastic and Sustainable Treatment Reduction against Parasitism in livestock). S. Ceriac was supported by a doctoral fellowship from la Région Guadeloupe and the animal genetics division of INRA.

\section{References}

Abbott, E.M., Parkins, J.J., Holmes, P.H., 1986. The effect of dietary protein on the pathophysiology of acute ovine haemonchosis. Vet. Parasitol. 20, 291-306.

Abbott, E.M., Parkins, J.J., Holmes, P.H., 1988. Influence of dietary-protein on the pathophysiology of haemonchosis in lambs given continuous infections. Res. Vet. Sci. 45, 41-49.

Adler, N., Bachmann, J., Blanckenhorn, W.U., Floate, K.D., Jensen, J., Rombke, J., 2016. Effects of ivermectin application on the diversity and function of dung and soil fauna: regulatory and scientific background information. Environ. Toxicol. Chem. 35, 1914-1923.

Alonso-Díaz, M.A., Torres-Acosta, J.F.J., Sandoval-Castro, C.A., Aguilar-Caballero, A.J. Hoste, H., 2008. In vitro larval migration and kinetics of exsheathment of Haemonchus contortus larvae exposed to four tropical tanniniferous plant extracts. Vet. Parasitol. 153, 313-319.

AOAC, 2006. Association of Official Analytical Chemists, 18th edition. Official Methods of Analysis, Gaithersburgs, MD.

Bambou, J.C., de la Chevrotiere, C., Varo, H., Arquet, R., Kooyman, F.N.J., Mandonnet, N., 2008. Serum antibody responses in Creole kids experimentally infected with Haemonchus contortus. Vet. Parasitol. 158, 311-318.

Bambou, J.C., Arquet, R., Archimede, H., Alexandre, G., Mandonnet, N., Gonzalez-Garcia, E., 2009. Intake and digestibility of naive kids differing in genetic resistance and experimentally parasitized (indoors) with Haemonchus contortus in two successive challenges. J. Anim. Sci. 87, 2367-2375.

Bambou, J.C., Larcher, T., Cei, W., Dumoulin, P.J., Mandonnet, N., 2013. Effect of Experimental Infection With Haemonchus Contortus on Parasitological and Local
Cellular Responses in Resistant and Susceptible Young Creole Goats. Biomed Research International.

Beynon, S.A., Wainwright, W.A., Christie, M., 2015. The application of an ecosystem services framework to estimate the economic value of dung beetles to the UK cattle industry. Ecol. Entomol. 40, 124-135.

Blackburn, H.D., Rocha, J.L., Figueiredo, E.P., Berne, M.E., Vieira, L.S., Cavalcante, A.R., Rosa, J.S., 1991. Interaction of parasitism and nutrition and their effects on production and clinical-parameters in goats. Vet. Parasitol. 40, 99-112.

Bricarello, P., Amarante, A., Rocha, R., Cabralfilho, S., Huntley, J., Houdijk, J., Abdalla, A., Gennari, S., 2005. Influence of dietary protein supply on resistance to experimental infections with in Ile de France and Santa Ines lambs. Vet. Parasitol. 134, 99-109.

Bueno, L., Dakkak, A., Fioramonti, J., 1982. Gastroduodenal motor and transit disturbances associated with Haemonchus contortus infection in sheep. Parasitology 84, 367-374.

Cei, W., Salah, N., Alexandre, G., Bambou, J.C., Archimede, H., 2018. Impact of energy and protein on the gastro-intestinal parasitism of small ruminants: a meta-analysis. Livest. Sci. 212, 34-44.

Ceriac, S., Archimede, H., Feuillet, D., Felicite, Y., Giorgi, M., Bambou, J.C., 2019. Supplementation with rumen-protected proteins induces resistance to Haemonchus contortus in goats. Sci. Rep. 9.

Ceriac, S., Jayles, C., Arquet, R., Feuillet, D., Felicite, Y., Archimede, H., Bambou, J.C., 2017. The nutritional status affects the complete blood count of goats experimentally infected with Haemonchus contortus. BMC Vet. Res. 13.

Churcher, T.S., Basanez, M.G., 2008. Density dependence and the spread of anthelmintic resistance. Evolution 62, 528-537.

Coop, R.L., Kyriazakis, I., 2001. Influence of host nutrition on the development and consequences of nematode parasitism in ruminants. Trends Parasitol. 17, 325-330.

Dawkins, H.J.S., Windon, R.G., Eagleson, G.K., 1989. Eosinophil responses in sheep selected for high and low responsiveness to Trichostrongylus colubriformis. Int. J. Parasitol. 19, 199-205.

Dorny, P., Vercruysse, J., 1998. Evaluation of a micro method for the routine determination of serum pepsinogen in cattle. Res. Vet. Sci. 65, 259-262.

Horvat, A.J.M., Petrovic, M., Babic, S., Pavlovic, D.M., Asperger, D., Pelko, S., Mance, A.D., Kastelan-Macan, M., 2012. Analysis, occurrence and fate of anthelmintics and their transformation products in the environment. Trac-Trends Analyt. Chem. 31, $61-84$.

Hoste, H., Torres-Acosta, J.F.J., Quijada, J., Chan-Perez, I., Dakheel, M.M., Kommuru, D.S., Mueller-Harvey, I., Terrill, T.H., 2016. Interactions between nutrition and infections with Haemonchus contortus and related gastrointestinal nematodes in small ruminants. In: Gasser, R.B., VonSamsonHimmelstjerna, G. (Eds.), Haemonchus contortus and Haemonchosis - Past, Present and Future Trends, pp. 239-351.

Houdijk, J.G.M., 2012. Differential effects of protein and energy scarcity on resistance to nematode parasites. Small Rumin. Res. 103, 41-49.

Jackson, F., Coop, R.L., 2000. The development of anthelmintic resistance in sheep nematodes. Parasitology 120, S95-S107.

Konwar, P., Tiwari, S.P., Gohain, M., Kumari, K., 2015. The effects of protein dietary supplementation on fecal egg counts and hematological parameters in goat kids with subclinical nematodosis. Vet. World 8, 1351-1355.

Mendez-Ortiz, F.A., Sandoval-Castro, C.A., Vargas-Magana, J.J., Sarmiento-Franco, L., Torres-Acosta, J.F.J., Ventura-Cordero, J., 2019. Impact of gastrointestinal parasitism on dry matter intake and live weight gain of lambs: a meta-analysis to estimate the metabolic cost of gastrointestinal nematodes. Vet. Parasitol. 265, 1-6.

Michael, E., Bundy, D.A.P., 1989. Density dependence in establishment, growth and worm fecundity in intestinal helminthiasis - the population biology of Trichuris muris (nematoda) infection in cba/ca mice. Parasitology 98, 451-458.

Papadopoulos, E., 2008. Anthelmintic resistance in sheep nematodes. Small Rumin. Res. 76, 99-103.

Ploeger, H.W., Everts, R.R., 2018. Alarming levels of anthelmintic resistance against gastrointestinal nematodes in sheep in the Netherlands. Vet. Parasitol. 262, 11-15.

Shaw, K.L., Nolan, J.V., Lynch, J.J., Coverdale, O.R., Gill, H.S., 1995. Effects of weaning, supplementation and gender on acquired-immunity to Haemonchus contortus in lambs. Int. J. Parasitol. 25, 381-387.

Strain, S.A.J., Stear, M.J., 2001. The influence of protein supplementation on the immune response to Haemonchus contortus. Parasite Immunol. 23, 527-531.

Sykes, A.R., 2010. Host immune responses to nematodes: benefit or cost? Implications for future development of sustainable methods of control. Rev. Bras. Zootec. 39, 376-382.

van Wyk, J.A., Bath, G.F., 2002. The FAMACHA(c) system for managing haemonchosis in sheep and goats by clinically identifying individual animals for treatment. Vet. Res. 33, 509-529.

Wallace, D.S., Bairden, K., Duncan, J.L., Fishwick, G., Holmes, P.H., McKellar, Q.A. Murray, M., Parkins, J.J., Stear, M., 1996. Influence of soyabean meal supplementation on the resistance of Scottish blackface lambs to haemonchosis. Res. Vet. Sci. $60,138-143$. 